\author{
Journal of International Business Research and \\ Marketing \\ Volume 4, Issue 1, 2018 \\ journal homepage: www.researchleap.com
}

\title{
Socioeconomic Impacts of Climate Extremes on American's Poverty-Related Human Needs (A New Approach by Nonprofits)
}

\author{
${ }^{1}$ Ali Farhan, ${ }^{2}$ Muhammad Hassan \\ ${ }^{1}$ The Center for Economic Research (CER), Shandong University Jinan, Shandong China \\ ${ }^{2}$ Interserve Learning and Employment UK plc
}

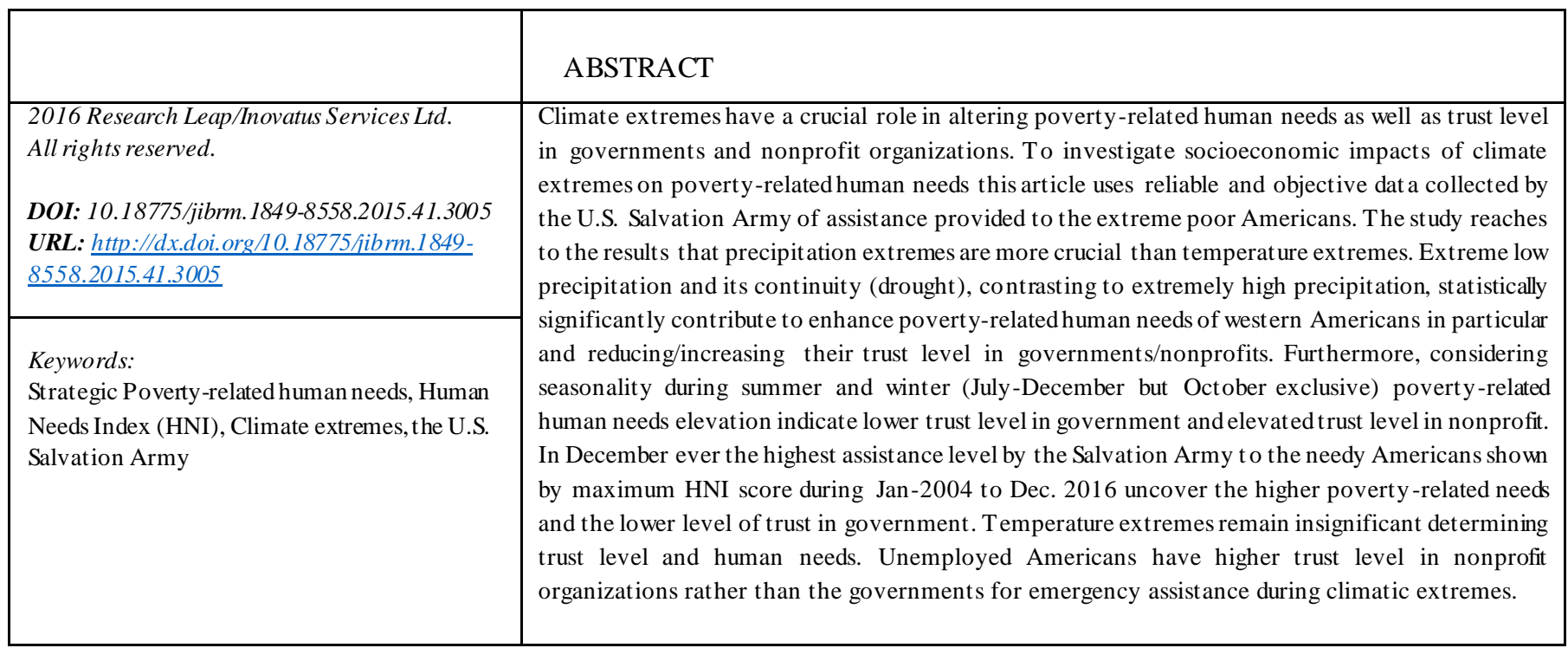

\section{Introduction}

"From recent disasters it has observed that the poor are much more likely to be negatively affected than their non-poor counterparts. As consequences of insufficient construction, dwellings of poor people are predominantly susceptible; and once affected have not enough savings to deal with the emergencies" (Nicaragua 2001).

Weather extremes (temperature \& precipitation extremes) and extreme events (continuity of temperature \& precipitation extremes) are projected by the scientists to happen in future with increased frequency and severity leading to exacerbate the challenges of poor households living in remote areas (J. M. Melillo, Terese, (T.C.), Richmond, G. W. Yohe). According to EM-DAT database (2015) extreme weather events pushed more than 4 billion homeless and injured individuals into emergency assistance needs worldwide during the last two decades (19952015). Floods, drought and extreme temperature jointly affected more than 3.5 billion people around the world during the same period. The United States accounted for one of the highest amounts of weather-related attributing too great diverse landmass and population concentration (EM-DAT, "The International Disaster Database").

Poor communities having a smaller amount of resources and less social relations may not well prepare to counter and recover from an extreme weather event(Frank Thomalla, Tom Downing, Erika Spanger-Siegfried, Guoyi Han, and Johan Rockström). Greater remote (very rural) and concentrated population areas having socioeconomic inequalities are often expected to have more distressed exposure to weather extremes and events than non-remote areas. Governments are generally thought to be ill-prepared in remote (rural) areas in planning and responding to climate change-induced extreme climatic conditions (J. M. Melillo et al). One of the largest nonprofit organization, the U.S. Salvation Army, notices the persistent poverty pockets as well as trust level of poor Americans in Government and nonprofits through Human Needs Index (HNI) (detailed description about HNI in Section3) which may not be noticeable from the traditional poverty measures particularly in greater remote and population concentrated areas of United States. 
Table1: Average HNI scores (January-2004 to Dec. 2016) demonstrating the highest poverty-related human needs and the lowest level of trust in governments, in remote and higher population concentrated areas

\begin{tabular}{llll}
\hline States & Region & $\begin{array}{l}\text { Average } \\
\text { HNI }\end{array}$ & $\begin{array}{l}\text { Population } \\
\text { density }\end{array}$ \\
\hline Arizona & $\begin{array}{l}\text { West } \\
\text { (Southwest) }\end{array}$ & 1.01 & 60.1 persons $/ \mathrm{km}^{2}$ \\
California & $\begin{array}{l}\text { West } \\
\text { (Southwest) }\end{array}$ & 1.34 & 251 persons $/ \mathrm{km}^{2}$ \\
Colorado & $\begin{array}{l}\text { West } \\
\text { (Southwest) }\end{array}$ & 0.90 & $52.6 \mathrm{persons} / \mathrm{km}^{2}$ \\
Michigan & $\begin{array}{l}\text { Central } \\
\text { (Midwest) }\end{array}$ & 1.62 & $174.7 \mathrm{persons} / \mathrm{km}^{2}$ \\
Nevada & $\begin{array}{l}\text { West } \\
\text { (Southwest) }\end{array}$ & 3.19 & $26.3 \mathrm{persons} / \mathrm{km}^{2}$ \\
Oregon & $\begin{array}{l}\text { West } \\
\text { (Northwest) }\end{array}$ & 0.67 & $42 \mathrm{persons} / \mathrm{km}^{2}$ \\
Utah & $\begin{array}{l}\text { West } \\
\text { (Southwest) }\end{array}$ & 0.41 & $36.5 \mathrm{persons} / \mathrm{km}^{2}$ \\
Washington & $\begin{array}{l}\text { West } \\
\text { (Northwest) }\end{array}$ & 1.25 & $107.8 \mathrm{persons} / \mathrm{km}^{2}$ \\
\hline
\end{tabular}

Source: Author himself constructed using data from https://humanneedsindex.org/ and U.S. Census Bureau, population estimates and American Community Survey (ACS), https://www.census.gov/programs-surveys/decennialcensus/data/datasets.2010.html.

Table2: Average HNI scores from (Jan-2004 to Dec-2016) demonstrating higher poverty-related human needs ${ }^{2}$ and lower trust in governments in remote and lower populationconcentrated areas

\begin{tabular}{|c|c|c|c|}
\hline States & Region & $\begin{array}{l}\text { Average } \\
\text { HNI }^{3}\end{array}$ & $\begin{array}{l}\text { Population } \\
\text { density }\end{array}$ \\
\hline Idaho & $\begin{array}{l}\text { West } \\
\text { (Northwest) }\end{array}$ & 0.75 & 20.0 persons $/ \mathrm{m}^{2}$ \\
\hline Kansas & Great Plains & 1.71 & 35.6 persons $/ \mathrm{m}^{2}$ \\
\hline Lowa & $\begin{array}{l}\text { Central } \\
\text { (Midwest) }\end{array}$ & 1.04 & 55.9 persons $/ \mathrm{m}^{2}$ \\
\hline Maine & Northeast & 0.72 & 43.1 persons $/ \mathrm{m}^{2}$ \\
\hline Minnesota & $\begin{array}{l}\text { Central } \\
\text { (Midwest) }\end{array}$ & 1.24 & 69.0 persons $/ \mathrm{m}^{2}$ \\
\hline Missouri & $\begin{array}{l}\text { Central } \\
\text { (Midwest) }\end{array}$ & 0.77 & 88.3 persons $/ \mathrm{m}^{2}$ \\
\hline Montana & $\begin{array}{l}\text { West } \\
\text { (Northwest) }\end{array}$ & 0.77 & 7.10 persons $/ \mathrm{m}^{2}$ \\
\hline Nebraska & $\begin{array}{l}\text { Central } \\
\text { (Midwest) }\end{array}$ & 1.19 & 24.7 persons $/ \mathrm{m}^{2}$ \\
\hline N. Mexico & $\begin{array}{l}\text { West } \\
\text { (Southwest) }\end{array}$ & 0.81 & 17.2 persons $/ \mathrm{m}^{2}$ \\
\hline N. Dakota & $\begin{array}{l}\text { Central } \\
\text { (Midwest) }\end{array}$ & 1.35 & 11.0 persons $/ \mathrm{m}^{2}$ \\
\hline Oklahoma & $\begin{array}{l}\text { Central } \\
\text { (Midwest) }\end{array}$ & 0.86 & 57.0 persons $/ \mathrm{m}^{2}$ \\
\hline S. Dakota & Great Plains & 0.95 & 11.3 persons $/ \mathrm{m}^{2}$ \\
\hline Wisconsin & $\begin{array}{l}\text { Central } \\
\text { (Midwest) }\end{array}$ & 1.32 & $\begin{array}{l}106.3 \\
\text { persons } / \mathrm{m}^{2}\end{array}$ \\
\hline
\end{tabular}

1HNI value starts from 0 (zero) meaning minimum human needs (i.e., emergency assistance).

2 There may be two plausible reasons of greater remote, highly concentrated and lower population concentrated states to show maximum and higher poverty-related
Source: Author himself constructed using data from https://humanneedsindex.org/ and U.S. Census Bureau, population estimates and American Community Survey (ACS), https://www.census.gov/programs-surveys/decennialcensus/data/datasets.2010.html

Table 1 Delineates average HNI scores (January-2004 to Dec. 2016) demonstrating the highest poverty-related human needs and the lowest level of trust in governments, in greater remote and higher population concentrated areas. It shows all the remote high population concentrated U.S. states carrying the highest human needs score in the west (southwest) exhibiting the highest emergency assistance for poverty-related human needs and the highest level of trust in the Salvation Army. Nevada shows the highest average HNI score demonstrating the highest poverty-related needs (i.e., the highest emergency assistance) to the poor Americans and the lowest trust level in government. On another side, Utah shows the lowest human needs (i.e., the least emergency as sistance) and the highest trust level in Governments among the highest human needs assistance provided states. At National level the highest HNI score implying the lowest trust level in government (i.e., highest level in the Salvation Army) stands at 1.33 in the year 2012 during 2004-2016 and average of National score stays at 1.09. Nevada's (3.19), Michigan (1.62), California (1.34), Washington (1.25), Arizona (1.09) shows higheror equal score than that of National HNI score where as Oregon (0.67), Utah (0.41) and Colorado (0.90) show lower than average National HNI score.

Table 2 Representing average HNI scores from (Jan-2004 to Dec-2016) demonstrate higher poverty-related human needs and lower trust in governments in greater remote and lower concentrated areas refers most of the remote low population concentrated U.S. states having higher human needs score in the Midwest, Great Plains exhibiting higher poverty-related human needs assistance and lower trust level in government. Kansas (1.71) shows average HNI score (i.e., touching the peak of the human needs as sis tance provided by the Salvation Army) and the higher level of trust in the Salvation Army and Maine (0.72) shows the lowest human needs assistance score having the lowest level of trust in the Salvation Army in the list of remote low population concentrated states. Kansas (1.71), Minnesota (1.24), Nebraska (1.19), North Dakota (1.35) and Wisconsin (1.32) shows higher HNI score than National average HNI whereas Idaho (0.75), Lowa (1.04), Maine (0.72), Missouri (0.77), Montana (0.77), New Mexico (0.81) and Wyoming (0.96) show lower than average National HNI score. Even though prospective impacts of climate change causing weather extremes and events in different regions have depicted

needs respectively, one limited access and low-income individuals as well as communities to the government services and second predominant dependence on social security network for assistance in need. 
from the existing literature, however the knowledge explaining the influences of climate extremes on basic human needs in the United States is very scant. To date, we are not familiar with any systematic research specifically investigating how climate extreme and events impact poverty-related human needs of Americans using nonprofits quality data collection.

Since it is widely evident that due to climate change in future weather extremes and extreme events can frequently occur with increased intensity around the globe, consequently poor communities in extreme event-prone regions may also require protecting mechanism. In lines with the point of action in publication of EM-DAT database 1995-2015, considering climate extremes at present and their potential frequent and intense occurrence in future as humanitarian concern this research aims to investigate in particular how the existing confronts of remote areas poor communities are affected and exacerbated by weather-associated extremes (i.e., floods, droughts, heat waves and cold winters) impacting their basic needs. This research aims to investigate how and which weather extremes (i.e., precipitation and temperature) and extreme weather events (i.e., Heat waves, Droughts, Cold winters, and Floods) as sequential of weather extremes in particular impact poverty-related human needs and social attitudes (i.e., trust level) towards governments or nonprofit organizations. By analysis of this research stakeholders, policymakers would enable to recognize to which key climatic extreme indicator poor Americans are at higher risks.

The analysis of this study bases on the following three observations. Poor communities are more vulnerable to climate extremes than their wealthy counterparts, and for weather extreme, particularly extreme heat susceptibility poverty is used as a proxy.

Non-metro (rural) communities are more likely to be poor than that of communities in metro areas in the United States of America.

Climate extreme and extreme events impacts vary regionally or geographically and impact not homogenously.This research has some limitations due to the unavailability of statewide monthly data of some related socioeconomic (i.e., income level) indicators. Furthermore, this research is divided into following sections, next section (1.1) explains the background, and section 2 is about regional socioeconomic vulnerability, section 3 discusses the material and methodology of this research, section 4 illustrates results and discussion in details and finally conclusion comes in section 5 .

\subsection{Background}

Historically the United States has been at higher risks of series of weather-related disasters ${ }^{4}$. For instance, the Dust Bowl in 1930 one of the worst weather-related disasters in the history of The United States and associated droughts in Midwest and Great Plains adversely affected all the country. Drought in 1988-89 has been economically the most distressing natural catastrophe in U.S. history (W. E. Riebsame). The most extensive drought in 2012 \& associated heat waves in summer affected over half of the U.S. through impacting mainly agriculture sectors, harvesting of corn, soybeans and other crops along with 123 fatalities and approximately $\$ 30.15$ billion losses.

Climate change induced weather extremes and events are having greater humanitarian concerns can have devastating impacts on humanity (S. Hales, S. J. Edwards, and R. S. Kovats), cold winters affected over 5 million Americans in central and southern areas of the U.S. during 2003-15. It has reported that every night approx. 30,000 homeless poor Americans are facing the extreme cold, extremely hot, hunger and the scarcity of drinking water need federal or social emergency assistance. According to an estimation of about 2 billion people might be dislocated or displaced until 2050 as a result of varying climate conditions. Also, Millions of people might be displaced in the future by extreme weather events as their impacts over the globe (O. Brown et al).

During the last three and half decades 196 extreme weather events have been encountered in the United States including 24 floods, 23 droughts, and 13 wildfires, seven freezes, 95 storms (including cold winter storms) and 34 hurricanes each event caused losses over the U.S. \$1billion (N. A. Ysasi, I. Marini, D. A. Harley, N. A. Ysasi, I. Marini, and D. A. Harley). Extreme weather events (i.e., droughts, floods and heat waves) are projected to occur more frequently with greater severity attributable to changing the climate in the next century which possibly will positively and negatively, directly and indirectly, impact human livelihoods.

Poor and low-income segments of the society already consume most of their earning proportion (about 25\%) for meeting basic needs i.e., food, water, energy etc. (T. C. Gap and R. MorelloFrosch). Weather extremes and events may exacerbate their existing challenges; geographically, isolated and greater remote area populations (rural) in particular are more likely to be affected as a result poor segments of the society have to face persistent poverty. 


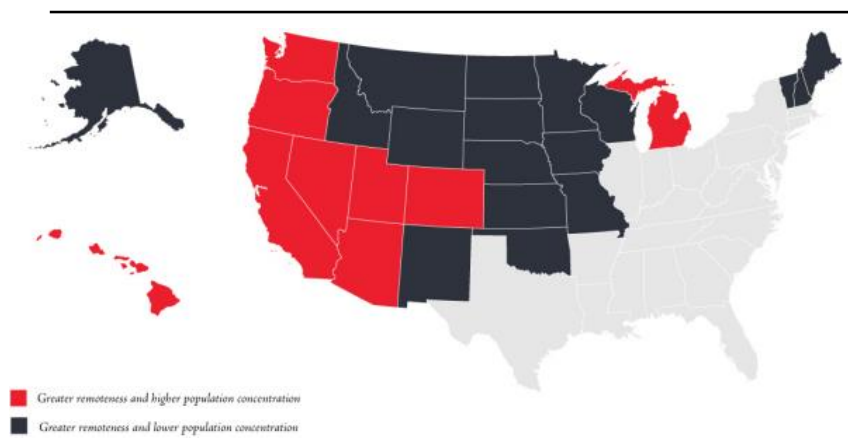

Figure 1: Persistent poverty pockets particularly in rural parts of the United States

Figure 1 presents persistent poverty pockets, particularly in the rural United States. In Figure 1 most of the highest povertyrelated needs and the highest trust level in the Salvation Army (i.e., Lower trust in Governments) indicating states with greater remoteness and higher population concentration have located in the Western United States, both southwest and northwest along with one in Midwest. Higher poverty-related needs states with greater remoteness and lower population concentration dominantly relate to the Midwest region.

Figure 2 presents poverty-related human needs assistance trends in the U.S. In Figure 2 the lowest value of HNI, 0, meaning the least human needs and the highest trust level in Governments, in 2012 all over the United States National HNI (1.33) touches the utmost human needs level. One of the plausible reasons for this acute enhance might be the most extensive drought in 2012 since 1930, and the associated heat wave in summer affected over $60 \%$ area of the United States..

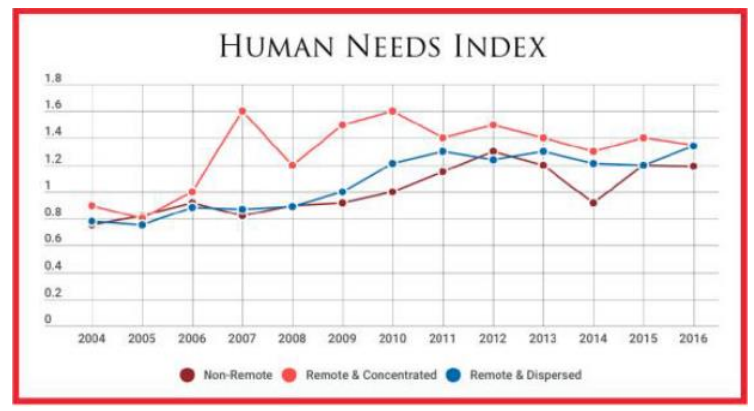

Figure 2: Poverty-related human needs assistance trends in the United States

\section{Source: http://www.humanneedsindex.org}

According to the United States Department of Agriculture (USDA) more than $80 \%$ of productive agricultural land was adversely affected, harvesting of corn, soybeans and other crops along with 123 fatalities and approximately $\$ 30.15$ billion losses and Hurricane Sandy in the eastern U.S. during last days of October 2012, made thousands of people homeless and millions of people left with no electricity. While during 2013-
14 human needs decrease as indicated by HNI (1.25), HNI (1.05) and in 2015-2016 slightly increase as HNI (1.25), HNI (1.24) respectively.

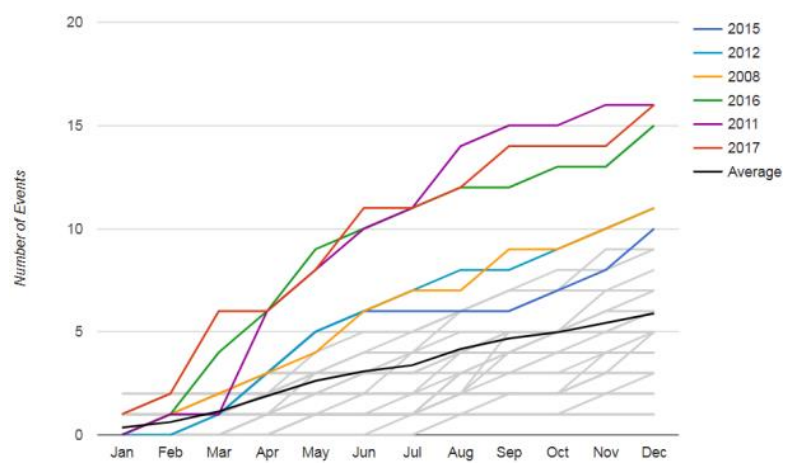

Figure 3: Weather extremes and extreme weather events occurred in the United States

Source: Reproduced from NOAA, https://www.ncdc.noaa.gov/billions/

Figure 3 concerns about weather extremes and extreme weather events occurred in the United States during the previous decade. In Figure 3, from 2002-2018, 14 drought events occurred, 17 flooding events and three freeze events in the United States, approximately losses from each climatic extreme have been more than $\$ 1$ billion (CPI-Adjusted).

We only noticed here the extreme events which are related to our study i.e., (droughts, floods, and cold winter events). Other extreme events like severe storms, wildfires also occurred during this period. The years 2011, 2016 and 2017 represent the highest number of extreme events. The higher number of climatic events has observed in summer, fall and winter as compared to spring.

Many researchers have illustrated that protective measures i.e., before time preparedness, reducing susceptibility and resilience construction taken today may possibly save communities from adverse impacts and a lot of money in the future. The United States may possibly save $\$ 4$ in the form of future happening adversity cost against every $\$ 1$ spent for protective measures today (T. E. Davies, N. Banjara, and T. Tregenza).

\section{Socioeconomic Regional Vulnerability}

The adverse impacts of extreme climatic situations vary geographically and regionally; particularly rural populations tend to experience in a disproportionate manner. As an example in the Midwest and the Great Plains population leading occupation farming are likely to face more impacts than any other region $[9,25]$.Approximately $14.13 \%$ (88\% in rural and $12 \%$ in urban) agriculture depending land area in the United States, been living source of at least $25 \%$ of labor and land owners on average per annum in 2010-2012. At least $13 \%$ of labor and land owners been earning from $7 \%$ of mining 
depending (83.3\% in rural and $16.7 \%$ in urban) area in 20102012. Most of the outdoor-recreation locations in the United States are located in rural areas $(68.77 \%$ of in rural as compared to $31.23 \%$ in urban) and most of the employees also reside in rural areas. Total federal govt. transfer dependent area $20.60 \%$ (56\% rural and $44 \%$ urban) in the United States. Federal government transfers account for $\sim 1 / 5$ th of rural revenue as compared to $\sim 1 / 8$ th of urban earnings. Rural communities being unable to meet with the changing climate vulnerability, particularly in Southeastern and Midwestern areas are more vulnerable as compared to their urban counterparts.

Lower education leads to lower income widening income gap in the communities (rural-urban), less competition and fewer high skilled jobs in non-metro job-related matrix (E. Miller, B. Antonny, S. Hamamoto, and R. Schekman) ultimately rural people tend to be persistently poor. Since income levels strongly influence weather variability (E. Miller, B. Antonny, S. Hamamoto, and R. Schekman) the vulnerability of rural communities to climatic conditions subject to be elevated. Lower education mostly in rural regions, higher drop out ratios delineate lower coping capacity and highly unfavorable outcomes to extreme weather events. In approximately $15 \%$ areas of The United States at least $20 \%$ of Americans of age in the range, 25-64 years have not completed high school education during 2008-12.

Historically, the poor and the marginalized in the United States have been at risk from extreme weather shocks than their wealthy counterparts (B. L. Turner II, R. E. Kasperson, and P. A. Matson). Low employments, less skilled or unskilled jobs imply lesser coping capacities and higher vulnerability to weather extremes. Less than $65 \%$ population of age between 25-64 years employed in low employment areas $(\sim 22.9 \%)$ during 2008-12.

Per capita rural income (\$38349), urban income (\$50861) in 2015 and rural-urban income gap (\$12512) which was (\$12829) in 2016 exhibit lower share of rural populations in skilled employment and lower earnings/returns to the college degree in markets. Southern and Western rural communities in the United States comprise $\sim 59 \%$ of the overall population in rural U.S. regions exhibit the highest poverty rates ultimately may require more emergency assistance in extreme climatic conditions.

High-poverty indicating areas are more likely to be clustered in the Southern states of the United States mainly in the corn-belt from a history of distressed and transmutation (transitioning) local economies, mostly low skills attribution to the racial/ethnic minorities and dependency on natural resources from the former times, nevertheless, West and Midwest areas are now evident of evolving poverty concentrations.

North/Eastern part of the United States representing over 25\% of the whole U.S. population (over $16 \%$ population of this region resides in non-metro counties) encounter various extreme climatic situations like hurricanes, extreme heat, floods, droughts and snow storms, etc. Rural are highly vulnerable to extreme heat due to infrastructure, housing construction, and low socioeconomic status, etc. They cannot afford air conditions during hotter days and heating units at homes in cold winter. Along with significantly varying topography in the north side of this region huge non-metro regions have lower temperature, particularly in winter having snowstorms in contrast to that of southern part's non-metro regions, experience higher temperature in summer and mild in winter (B. L. Turner II, R. E. Kasperson, and P. A. Matson).

The temperature in this region has increased on average about $2^{\circ} \mathrm{F}$ in the preceding century and is predicted to rise about $4^{\circ} \mathrm{F}$ to $10^{\circ} \mathrm{F}$ in the last quarter of this century. Precipitation has increased in winter and spring at most in the United States as compared to other regions, in the five decades it has augmented by $70 \%$. Predictions of increasing temperature and precipitation are likely to adversely impact agriculture and human lives in the region ( $\mathrm{R}$. Horton et al).

As in central/Midwestern region over $24 \%$ of the United States total population along with more than $22 \%$ rural population (S. C. Pryor and R. J. Barthelmie), anthropogenic activities predominantly bring local communities at higher risk to lower temperature i.e., freezing in winter, heat waves, tornadoes, and droughts. Weather-Related extremes significantly threaten public health. Flooding events are also frequent in this region, as an example, flood in 2008 caused about 25 deaths, significantly impacted farming yields, and infrastructure, total losses equating US\$15billion (G. P. Roberson et al).

Furthermore, severe floods in 2013-14 in Michigan, Missouri, Lowa, Illinois and Indiana adversely affected agriculture dependent communities damaged homes, destroyed businesses, thousands of vehicles (cars) and properties. During the last century, the temperature has increased by about $1.5^{\circ} \mathrm{F}$ in the Midwestern the United States and is expected to further increase in this century. Precipitation has increased by about $20 \%$ in some areas particularly in eastern Midwest areas and is also projected to increase in spring and winter; however, summer will be hotter and drier particularly in southem Midwest areas disrupting water sources leading to elevate energy demands for air conditions in particular.

The Southeastern United States contains over $30 \%$ of the total U.S. population including more than $26 \%$ of the rural population. Same like other regions this region also encounters hurricanes, extreme heat, droughts, tornadoes and blizzard, etc. (L. M. Carter et al). Rural populations are highly vulnerable to droughts and rural coastal e.g. Louisiana, Florida and South Carolina communities are substantially affected by floods (D.C. Morton, M.E. Roessing, A.E. Camp, and M.L. Tyrrell). Since the last five decades average temperature particularly in summer has risen by $2^{\circ} \mathrm{F}$ which is further expected to rise by 
about $4^{\circ} \mathrm{F}$ to $8^{\circ} \mathrm{F}$ at the end of this century. Despite of some areas in this region heavy precipitations are common in this region, and also anticipated to increase in this century. Human health and agriculture are probable to be at greater risk in the future due to higher water demands in response to rising temperature and flooding particularly in coastal areas (L. M. Carter et al).

Southwestern region of the United States is the driest and the hottest area, the home of more than $22 \%$ of the U.S. population. Increased wildfires (i.e., $\sim 650 \%$ ) attributable to severe heat waves damaged thous ands of homes, increased health problems (G. Garfin et al). California being the most productive state in the United States has been experiencing drought situations since last decade and leading seasonal fire all around with extremely high temperature. Further increase in temperature and decrease in precipitation due to changing the climate in the hottest and drier region can increase food unavailability and energy supply challenges in response to water shortage heightening competition of water usage between agriculture and energy production.

The average temperature has increased by approx $1.3^{\circ} \mathrm{F}$ and precipitation has decreased in the Northwestern United States during the last century. At the end of this century, projection of increasing average temperature by 3 to $10^{\circ} \mathrm{F}$ and decreasing precipitation on average by about $30 \%$ particularly in summer will be increasing water shortage, agricultural production loss, affecting hydroelectric supply, since $40 \%$ of the hydroelectricity of the United States is produced in this region (P. Mote and A. Snover).

\section{Material and Methods}

Despite growing American economy more people found in poverty during the last decade. Millions of the poor Americans face extreme poverty conditions, particularly in remote rural areas. According to an estimation, more than $15 \%$ of the U.S. population (more than 45 million)is facing extreme poverty situation. The researchers and the policymakers increased their focus to find a sensitive and timely (with no lag) poverty detecting measure in place of existing poverty measures because of poverty rate increased about 27\% between 2006 (including great depression 2008 era) and 2010 (K. Seefeldt et al).

\subsection{Overview of the HNI}

The U.S. Salvation Army together with Lilly Family School of Philanthropy Indiana University created the earliest and translucent quantifying perspective of poverty-relevant human needs by scrutiny of longitudinal service facts and figures of nonprofit societal services to the millions of extreme poor Americans across time as well as region. Human Needs Index (HNI) focusing extreme poor segments of the society comprises of seven basic need indicators; food stipulation, meal provision, shelter or home assistance, clothing provision, energy stipulation, medical assistance and furniture provision. Climatic extremes and seasonality are one of the most important human needs determining indicators. HNI also delineates heightened sensitivity to both varying weather conditions and seasonality. HNI being unique and modern poverty perspective has merits as well as some demerits as; HNI employs a scientific, logical and entrenched econometric process to track human needs over time. It denotes the depth of poverty in American poor communities embodying consumption more willingly than income. In contrast to the existing poverty measures HNI measures level of needs among extreme poor individuals and communities with no lag. As it is argued that elderly and low-income households specifically in summer and winter that may not afford increased burden of energy costs are mainly at higher risks of extreme weather events. In addition, a large number of low-incomes poor African Americans and Hispanics (Latinos) do not afford air conditioners in extreme weather condition i.e., extreme hot. Even it is just beyond the social security provision area of the Salvation Army's HNI. In other words, HNI does not provide any information about assisting service to distinct racial/ethnic groups or communities and gender.

\subsection{Determining Thresholds for Climatic Extremes}

Infrequently incidence of value of climate variables i.e., temperature or precipitation lower or higher than a threshold level in the range of observed values of climatic variables can be termed as weather extreme and the persistence of weather extremes for some period of time (i.e., hourly, daily, weekly, monthly) referred as an extreme weather event (E. Bucchignani et al). Extreme value as occurring below or above a threshold level closer to the lower or higher ends of data range of a variable (S. K. Allen et al).

Due to unavailability of universal definitions of weather extremes and extreme weather events we face many challenges while defining specific weather conditions. Since there is no generally accepted way to describe extreme weather events, though either they can explain characteristic of weather variables (e.g., Temperature, precipitation) or their impacts since consecutively to build a sense the statement entails that the description of an extreme is independent of observed or predictable values which establish the norm (M. Jahn).

W. Schlenker and M. J. Roberts propose maximum temperature thresholds; $29^{\circ} \mathrm{C}$ for corn, $30^{\circ} \mathrm{C}$ for soybeans and $32^{\circ} \mathrm{C}$ for cotton outputs to enhance however possibly beyond these threshold levels, the temperature might be very detrimental. We have chosen here two thresholds for average temperature $28^{\circ} \mathrm{C}$ and $30^{\circ} \mathrm{C}$ (average of three above proposed threshold levels) beyond that considered as extreme heat (an extreme weather event) in the current research.

Southeastern which is thought to be among one of the warmer U.S. regions thresholds for extreme high temperature $35^{\circ} \mathrm{C}$, 
extreme low-temperature thresholds $-2^{\circ} \mathrm{C}$ and thresholds of extremely high precipitation $102 \mathrm{~mm}$ from 1948-2012 on a daily basis have utilized in a study (E. J. Powell and B. D. Keim).

Beyond extreme temperature threshold $30^{\circ} \mathrm{C}$ reduced rate of heat-related mortality was found as $41,17.3$ and 10.5 during 1960-70, 1980 and 1990 respectively in 28 cities of the United States. This mortality rate is for every million people (O. Deschênes and M. Greenstone, S. J. Zivin). For every $1^{\circ} \mathrm{C}$ increase in temperature in developed nations beyond absolute thresholds $27^{\circ} \mathrm{C}-29^{\circ} \mathrm{C}$ in a day rate of mortality of adults increases 2 to $3 \%$ and among children, it can raise $50-100 \%$ more than that of adult's mortality rate (S. Lin et al). Also, it also has been concluded that beyond temperature threshold $32^{\circ} \mathrm{C}$ on daily basis data death rate significantly amplifies, i.e., (three times higher) as compared to death rate at $26^{\circ} \mathrm{C}(\mathrm{K} . \mathrm{E}$. Kunkel et al,. F. Ackerman and E. a Stanton). In New York, every $1{ }^{\circ} \mathrm{C}$ rise in temperature on a day beyond $29-36^{\circ} \mathrm{C}$ causes to increase the rate of hospital admissions for cardiovascular and respiratory diseases up to 2.7 percent-3.1 percent on that same day particularly in Hispanics $(\sim 6 \%)$ and elder ones $(\sim 4.5 \%)$ (S. Lin et al).

Emphasizing limitations of this research, we cannot include income which is one of the socioeconomic indicators in our analysis due to the unavailability of statewide monthly data. Consequently, we chose HNI as a poverty measure, to capture climatic conditions, along with the weather-related indicators, i.e., (precipitation and average temperature), unemployment as unemployment rate; latitude and longitude as controlled indicators because unemployment, particularly in rural areas, is a human need determinant.

In Table 3, for better understanding, we use two OLS models with little changing thresholds for climate extremes. We chose absolute threshold level (value) for temperature $\left(28^{\circ} \mathrm{C}\right.$ for hot and $5^{\circ} \mathrm{C}$ for cold) for model 1 whereas $30^{\circ} \mathrm{C}$ and $0^{\circ} \mathrm{C}$ for hot 1 and cold 1 in model 2 respectively, percentiles criteria for precipitation thresholds as beyond $90^{\text {th }}$ percentile for high precipitation and $10^{\text {th }}$ percentile for low precipitation for model 1, little higher than $95^{\text {th }}$ percentile and 5 percentile for high precipitation 1 and low precipitation 1 in model 2 respectively. This research uses strongly balanced panel data and different data sources consulted for the required data. Precipitation and average temperature data are obtained from the same source $\mathrm{NOAA}^{5}$, data of unemployment rate obtained from U.S. Census Bureau ${ }^{6}$ and for latitude and longitude.
Table 3: Thresholds ${ }^{7}$ for weather extremes and extreme events

\begin{tabular}{|c|c|}
\hline Model 1 & Model 2 \\
\hline $\begin{array}{l}\text { Hot: If the average Temp is } \geq \\
28^{\circ} \mathrm{C} \text { then } \mathrm{D}=1,0 \text { otherwise }\end{array}$ & $\begin{array}{l}\text { Hot 1: If the average Temp is } \geq 30^{\circ} \mathrm{C} \\
\text { then } \mathrm{D}=1,0 \text { otherwise }\end{array}$ \\
\hline $\begin{array}{l}\text { Cold: If the Avg. Temp is } \leq 5^{\circ} \mathrm{C} \\
\text { then } \mathrm{D}=1,0 \text { otherwise }\end{array}$ & $\begin{array}{l}\text { Cold 1: If the Avg. Temp is } \leq 0^{\circ} \mathrm{C} \\
\text { then } \mathrm{D}=1,0 \text { otherwise }\end{array}$ \\
\hline $\begin{array}{l}\text { Low Precipitation: If } \\
\text { Precipitation is } \leq 10 \mathrm{~mm} \text { then } \mathrm{D}= \\
1,0 \text { otherwise }\end{array}$ & $\begin{array}{l}\text { Low Precip. 1: If Precipitation is } \leq \\
20 \mathrm{~mm} \text { then } \mathrm{D}=1,0 \text { otherwise }\end{array}$ \\
\hline $\begin{array}{l}\text { High Precipitation: If } \\
\text { Precipitation is } \geq 200 \mathrm{~mm} \text { then } \mathrm{D} \\
=1,0 \text { otherwise }\end{array}$ & $\begin{array}{l}\text { High Precipitation 1: If } \\
\text { Precipitation is } \geq 220 \mathrm{~mm} \text { then } \mathrm{D}= \\
1,0 \text { otherwise }\end{array}$ \\
\hline $\begin{array}{l}\text { Heat Wave: If for } 2 \text { or more } \\
\text { consecutive months Avg. Temp. } \\
\text { is }>28^{\circ} \mathrm{C} \text { then } \mathrm{D}=1,0 \text { otherwise }\end{array}$ & $\begin{array}{l}\text { Heat Wave 1: If for } 2 \text { or more } \\
\text { consecutivemonths Avg. Temp. is }> \\
30^{\circ} \mathrm{C} \text { then } \mathrm{D}=1,0 \text { otherwise }\end{array}$ \\
\hline $\begin{array}{l}\text { Drought: If for } 2 \text { or more } \\
\text { consecutive months Precipitation } \\
\text { is }<10 \mathrm{~mm} \text { then } \mathrm{D}=1,0 \text { otherwise }\end{array}$ & $\begin{array}{l}\text { Drought 1: If for } 2 \text { or more } \\
\text { consecutive months Precipitation is } \\
<20 \mathrm{~mm} \text { then } \mathrm{D}=1,0 \text { otherwise }\end{array}$ \\
\hline $\begin{array}{l}\text { Cold Winter: If for } 3 \text { or more } \\
\text { consecutivemonths Avg Temp. is } \\
<5^{\circ} \mathrm{C} \text { then } \mathrm{D}=1,0 \text { otherwise }\end{array}$ & $\begin{array}{l}\text { Cold Winter 1: If for } 3 \text { or more } \\
\text { consecutivemonths Avg. Temp. is }< \\
0^{\circ} \mathrm{C} \text { then } \mathrm{D}=1,0 \text { otherwise }\end{array}$ \\
\hline $\begin{array}{l}\text { Flood: If for } 2 \text { or more } \\
\text { consecutive months Precipitation } \\
\text { is }>200 \mathrm{~mm} \mathrm{D}=1,0 \text { otherwise }\end{array}$ & $\begin{array}{l}\text { Flood 1: If for } 2 \text { or more consecutive } \\
\text { months Precipitation is }>220 \mathrm{~mm} \\
\text { then } D=1,0 \text { otherwise }\end{array}$ \\
\hline
\end{tabular}

\subsection{Econometric Models for Estimation}

Varying weather conditions are expected and will continue to impact poor individuals and communities in a more disproportionate manner than rich counterparts specifically in remote and population concentrated areas. For instance, the United States consisting of vast geographic location historically has been under series of extreme weather events, droughts in particular as, in 2009 adversely impacted agriculture sector in Southwest, Midwest, and Great plains along with about \$5.2billion money losses, maximum losses in California and Texas. Arizona, Kansas, New Mexico, LA, Texas and Oklahoma were affected by drought and heat wave particularly during growing season in 2011, 95 fatalities and losses in monetary terms approximately $\$ 12.2$ billion are separate. The most extensive drought (2012) ever in The United States since $1930 \&$ associated heat wave in summer affected over half of the U.S. specifically agricultural states, harvesting of corn, soybeans and other crops, 123 fatalities and approximately $\$ 30.15$ billion losses exclusive. Agriculture sector continued to be highly impacted by drought in California, some of other western states whereas in Texas \& Oklahoma situation improved by some of flood events along with other losses equating to about $\$ 4.5$ billion. 
For empirical estimation of how poor Americans are impacted by weather extremes and events, in other words how poverty-related human needs change in response to acute temperature and its continuity as well as extreme precipitation and its sequence we use two basic econometric models.

$\mathrm{HNI}_{\mathrm{it}}=\beta_{0}+\sum_{\mathrm{j}=1}^{\mathrm{N}} \beta_{1 \mathrm{j}} \mathrm{D}_{\mathrm{ji}}+\beta_{2 \mathrm{i}} \mathrm{x}_{2 \mathrm{it}}+\beta_{3 \mathrm{i}} \mathrm{x}_{3 \mathrm{it}}+\beta_{4 \mathrm{i}} \mathrm{x}_{4 \mathrm{it}}+$ $\varepsilon_{\text {it }}$

$$
\begin{gathered}
\mathrm{HNI}_{\mathrm{jt}}=\beta_{0}+\sum_{\substack{\mathrm{k}=1\\
}}^{\mathrm{N}} \beta_{1 \mathrm{k}} \mathrm{D}_{\mathrm{jk}}+\beta_{2 \mathrm{j}} \mathrm{x}_{2 \mathrm{jt}}+\beta_{3 \mathrm{j}} \mathrm{x}_{3 \mathrm{jt}}+\beta_{4 \mathrm{j}} \mathrm{x}_{4 \mathrm{jt}} \\
\quad \text { (2) }
\end{gathered}
$$

In both the models, model 1 and 2 , HNI is human needs index indicating HNI score in ' 1 th state in $\mathrm{t}$ ' time, $\beta_{0}$ is an intercept, $D_{\mathrm{jt}}$ represents explanatory dummies of key weather indicators as weather extremes and events, $\beta_{1 j}$ represents slope of $\mathrm{j}^{\text {th }}$ dummy (in the equation of Model 2) of weather extreme, $\beta_{2 i} x_{2 i t}, \beta_{3 i} x_{3 i t}, \beta_{4 i} x_{4 i t}$ represent controlled variables along with their regression coefficients and $\varepsilon_{i t}$ is stochastic error term (varies over time). In both the models' Human needs index (HNI) as an explained indicator, weather-related indicators (dummy variables) as an explanatory and key indicators, (also see Table 3). The dummies for key weather explanatory variables Hot (Hot1), Cold (Cold1), Heatwave (Heat wave1) and cold winter (cold winter1) are created from the average temperature and the dummies Low precipitation (Low precipitation1), High precipitation (High precipitation1), Drought (Drought1) and Flood (Flood1) are created from precipitation. We use pooled OLS regression for the analysis and to attain the results.

\section{Results and Discussions}

\subsection{Preliminary Results and Discussion}

The statewide monthly HNI largely varies in a complex manner in U.S. ranges between ' 0 to 28.7 ' with an average score of 0.995 and standard deviation 0.985 throughout the strongly balanced panel dataset (2004January-2016Dece mber). Average temperature and precipitation vary in the range $-24.9^{\circ} \mathrm{C}-$ $31.8^{\circ} \mathrm{C}$ with average (mean) $11.08^{\circ} \mathrm{C}$, standard deviation $10.04^{\circ} \mathrm{C}$ and $0.25 \mathrm{~mm}-404.4 \mathrm{~mm}$ with mean $78.83 \mathrm{~mm}$ and standard deviation $51.15 \mathrm{~mm}$ respectively. All the extreme weather indicating dummies created from key weather indicators (temperature, precipitation) vary in the range ' 0 to 1 '. Controlled variables, i.e., the statewide monthly unemployment rate remains in the range $2.3 \%-14.9 \%$ (mean 6.34 and std. deviation 2.19) throughout the United States following the dataset range 2004January-2016December. Lastly, geographic directed indicators latitude and longitude follows the range $27.83^{\circ} \mathrm{N}$ to $61.38^{\circ} \mathrm{S}$ (mean $39.81^{\circ}$, std. deviation $5.57^{\circ}$ ) and $152.3^{\circ}$ East to $-72.76^{\circ}$ West (mean $-86.7^{\circ}$, std. deviation $12.15^{\circ}$ ) throughout the United States.

Table 4 in section 4.2 demonstrates a descriptive statistic of all the indicators included in this study.

\begin{tabular}{|c|c|c|c|c|c|}
\hline Indicators & O bs. & Mean & $\begin{array}{l}\text { Std. } \\
\text { Dev. }\end{array}$ & Min. & Max. \\
\hline HNI & 7488 & 0.995 & 0.985 & 0 & 28.7 \\
\hline $\begin{array}{l}\text { Avg. } \\
\text { Temperature }\end{array}$ & 7488 & 11.08 & 10.04 & -24.9 & 31.8 \\
\hline Precipitation & 7488 & 78.83 & 51.15 & 0.25 & 404.4 \\
\hline \multicolumn{6}{|l|}{$\begin{array}{l}\text { Weather } \\
\text { Extremes }\end{array}$} \\
\hline Hot & 7488 & 0.011 & 0.106 & 0 & 1 \\
\hline Hot 1 & 7488 & 0.001 & 0.028 & 0 & 1 \\
\hline Cold & 7488 & 0.292 & 0.455 & 0 & 1 \\
\hline Cold 1 & 7488 & 0.159 & 0.365 & 0 & 1 \\
\hline $\begin{array}{l}\text { Precipitation } \\
\text { Low }\end{array}$ & 7488 & 0.047 & 0.212 & 0 & 1 \\
\hline \multicolumn{6}{|l|}{$\begin{array}{l}\text { Precip.Lowl } \\
\text { Extreme }\end{array}$} \\
\hline $\begin{array}{l}\text { Weather } \\
\text { Events }\end{array}$ & 7488 & 0.110 & 0.313 & 0 & 1 \\
\hline Heat Wave & 7488 & 0.003 & 0.057 & 0 & 1 \\
\hline Heat Wave 1 & 7488 & 0.000 & 0.018 & 0 & 1 \\
\hline Cold winter & & 0.153 & 0.360 & 0 & 1 \\
\hline Cold winter 1 & 7488 & 0.057 & 0.232 & 0 & 1 \\
\hline Drought & 7488 & 0.057 & 0.232 & 0 & 1 \\
\hline Drought 1 & 7488 & 0.052 & 0.223 & 0 & 1 \\
\hline Flood & 7488 & 0.002 & 0.046 & 0 & 1 \\
\hline $\begin{array}{l}\text { Flood } 1 \\
\text { Controlled } \\
\text { Variables }\end{array}$ & & 0.002 & 0.039 & 0 & 1 \\
\hline $\begin{array}{l}\text { Unemployme } \\
\text { nt Rate }\end{array}$ & 7488 & 6.338 & 2.193 & 2.3 & 14.9 \\
\hline Latitude & 7488 & 39.81 & 5.572 & 27.8 & 61.38 \\
\hline Longitude & 7488 & -86.7 & 12.15 & -152.3 & -72.76 \\
\hline
\end{tabular}

Table 4: Descriptive Statistics

Table 5 presents pooled OLS regression seasonality results for two models, Model 1 and Model 2 respectively. Model 1 has four sub-models as model 1a to model 1d. Model lapresents the outcome of weather extremes in the form of regression coefficients and seasonality referring coefficients. Model $1 \mathrm{~b}$ includes extreme weather events along with weather extremes and seasonality coefficients. Model 1c further includes control variable unemployment rate along with weather extremes, extreme weather events and seasonal regression coefficients and finally, model $1 \mathrm{~d}$ comprises of another control variable latitude and longitude along with results of model 1c. The same practice is repeated in Model 2 inTable 6. First, we will explain the results of Model 1, Table 5 in details and then we will move towards model 2, Table 6 .

See (Table 5) Low precipitation ( $\leq 10 \mathrm{~mm}$ ) significantly (at $1 \%$ level of significance) affects human needs keeping all other indicators constant or unchanged, contributing to increase HNI score by 0.37 on average delineating higher poverty-related human needs assistance, whereas increase by HNI score 0.371 , $0.380,0.404,0.313$ in models from model 1a to model $1 \mathrm{~d}$ respectively. Contrasting to low precipitation, high precipitation ( $\geq 200 \mathrm{~mm}$ ) contributes to decrease human needs by 0.17 score on average keeping all other indicators constant or unchanged in all sub-models from model 1a to model 1d, 
however in model 1a, high precipitation causes to reduce human needs by score 0.156 , in model $1 \mathrm{~b}$ after inclusion of extreme events causes to reduce human needs by score 0.164 , including unemployment rate in model 1c human needs reduce by HNI score 0.202 and in model $1 \mathrm{~d}$ by including all explanatory indicators along with latitude, longitude $1 \mathrm{~mm}$ precipitation beyond $200 \mathrm{~mm}$ may cause to reduce human needs by score 0.159 . Rest of all the weather-related indicators in this study presents an insignificant association with poverty-related human needs.

Unemployment and geographic locations which are considered important human needs determining indicators significantly associated with HNI score indicating a strong association with human needs. $1 \%$ change (increase/decrease) in unemployment rate may change (increase/decrease) human needs assistance through social security network of the Salvation Army by score 0.0695 on average (statistically significant at $1 \%$ level of significance), longitude results show that from west to south poverty-related human needs as sistance through social security network decreases like $1^{\circ}$ movement from Western to Eastern areas in The United States may reduce human needs by score 0.006 on average, whereas from North to South (latitude) results are not significant. Robust seasonality results reveal the implications of all these results for Model 1 during Fall-Winter season (August to December, October exclusive) showing statistically higher significance ( $1 \%$ significance level), particularly in December. (The month of the highest povertyrelated human needs ever).

Table 5: Pooled-OLS Seasonality Results of Model 1

\begin{tabular}{|c|c|c|c|c|}
\hline & Model 1a & Model 1b & Model 1c & Model 1d \\
\hline HNI & $\begin{array}{l}\text { Coefficien } \\
\text { ts } \\
\text { (Standard } \\
\text { Error) }\end{array}$ & $\begin{array}{l}\text { Coefficien } \\
\text { ts } \\
\text { (Standard } \\
\text { Error) }\end{array}$ & $\begin{array}{l}\text { Coefficients } \\
\text { (Standard } \\
\text { Error) }\end{array}$ & $\begin{array}{l}\text { Coe fficien } \\
\text { ts } \\
\text { (Standard } \\
\text { Error) }\end{array}$ \\
\hline \multicolumn{5}{|l|}{$\begin{array}{l}\text { Weather } \\
\text { Extremes }\end{array}$} \\
\hline Hot & $\begin{array}{l}0.182 \\
(0.115)\end{array}$ & $\begin{array}{l}0.218 \\
(0.135)\end{array}$ & $\begin{array}{l}0.214 \\
(0.134)\end{array}$ & $\begin{array}{l}0.228^{*} \\
(0.134)\end{array}$ \\
\hline Cold & $\begin{array}{l}0.041 \\
(0.038)\end{array}$ & $\begin{array}{l}0.046 \\
(0.048)\end{array}$ & $\begin{array}{l}0.076 \\
(0.047)\end{array}$ & $\begin{array}{l}0.044 \\
(0.049)\end{array}$ \\
\hline $\begin{array}{l}\text { Low } \\
\text { Precipitation }\end{array}$ & $\begin{array}{l}0.371 * * * \\
(0.057)\end{array}$ & $\begin{array}{l}0.380 * * * \\
(0.072)\end{array}$ & $\begin{array}{l}0.408 * * *(0.07 \\
1)\end{array}$ & $\begin{array}{l}0.313 * * * \\
(0.071)\end{array}$ \\
\hline $\begin{array}{l}\text { High } \\
\text { Precipitation }\end{array}$ & $\begin{array}{l}-.156 * * \\
(0.079)\end{array}$ & $\begin{array}{l}-.164 * * \\
(0.083)\end{array}$ & $\begin{array}{l}-.202 * * \\
(0.082)\end{array}$ & $\begin{array}{l}-.159 * * \\
(0.081)\end{array}$ \\
\hline \multicolumn{5}{|l|}{$\begin{array}{l}\text { Extreme } \\
\text { Events }\end{array}$} \\
\hline Heat Wave & & $\begin{array}{l}-.1270 \\
(0.250)\end{array}$ & $\begin{array}{l}-.181 \\
(0.247)\end{array}$ & $\begin{array}{l}-.184 \\
(0.245)\end{array}$ \\
\hline Cold winter & & $\begin{array}{l}-.0100 \\
(0.055)\end{array}$ & $\begin{array}{l}0.004 \\
(0.054)\end{array}$ & $\begin{array}{l}-.039 \\
(0.054)\end{array}$ \\
\hline Drought & & $\begin{array}{l}-.0240 \\
(0.114)\end{array}$ & $\begin{array}{l}-.077 \\
(0.113)\end{array}$ & $\begin{array}{l}-.101 \\
(0.112)\end{array}$ \\
\hline
\end{tabular}

\begin{tabular}{|c|c|c|c|c|}
\hline Flood & & $\begin{array}{l}0.087 \\
(0.270)\end{array}$ & $\begin{array}{l}0.140 \\
(0.267)\end{array}$ & $\begin{array}{l}0.133 \\
(0.265)\end{array}$ \\
\hline \multicolumn{5}{|l|}{$\begin{array}{l}\text { Controlled } \\
\text { Variables }\end{array}$} \\
\hline $\begin{array}{l}\text { Unemployme } \\
\text { nt Rate }\end{array}$ & & & $\begin{array}{l}0.069 * * * \\
(0.005)\end{array}$ & $\begin{array}{l}0.070 * * * \\
(0.005)\end{array}$ \\
\hline Latitude & & & & $\begin{array}{l}0.002 \\
(0.003)\end{array}$ \\
\hline Longitude & & & & $\begin{array}{l}-.006 * * * \\
(0.000)\end{array}$ \\
\hline \multicolumn{5}{|l|}{$\begin{array}{l}\text { Seasonality } \\
\text { Results }\end{array}$} \\
\hline February & $\begin{array}{l}-.085 \\
(0.057)\end{array}$ & $\begin{array}{l}-.082 \\
(0.058)\end{array}$ & $\begin{array}{l}-.082 \\
(0.057)\end{array}$ & $\begin{array}{l}-.076 \\
(0.057)\end{array}$ \\
\hline March & $\begin{array}{l}0.044 \\
(0.058)\end{array}$ & $\begin{array}{l}0.047 \\
(0.059)\end{array}$ & $\begin{array}{l}0.058 \\
(0.058)\end{array}$ & $\begin{array}{l}0.045 \\
(0.058)\end{array}$ \\
\hline April & $\begin{array}{l}0.010 \\
(0.063)\end{array}$ & $\begin{array}{l}0.011 \\
(0.063)\end{array}$ & $\begin{array}{l}0.032 \\
(0.063)\end{array}$ & $\begin{array}{l}-.008 \\
(0.063)\end{array}$ \\
\hline May & $\begin{array}{l}0.040 \\
(0.064)\end{array}$ & $\begin{array}{l}0.040 \\
(0.065)\end{array}$ & $\begin{array}{l}0.065 \\
(0.064)\end{array}$ & $\begin{array}{l}0.018 \\
(0.065)\end{array}$ \\
\hline June & $\begin{array}{l}0.033 \\
(0.065)\end{array}$ & $\begin{array}{l}0.033 \\
(0.065)\end{array}$ & $\begin{array}{l}0.058 \\
(0.064)\end{array}$ & $\begin{array}{l}0.012 \\
(0.066)\end{array}$ \\
\hline July & $\begin{array}{l}0.140 * * \\
(0.065)\end{array}$ & $\begin{array}{l}0.139 * * \\
(0.065)\end{array}$ & $\begin{array}{l}0.164 * * \\
(0.065)\end{array}$ & $\begin{array}{l}0.117^{*} \\
(0.066)\end{array}$ \\
\hline August & $\begin{array}{l}0.200 * * * \\
(0.066)\end{array}$ & $\begin{array}{l}0.202 * * * \\
(0.066)\end{array}$ & $\begin{array}{l}0.231 * * * \\
(0.065)\end{array}$ & $\begin{array}{l}0.183 * * * \\
(0.066)\end{array}$ \\
\hline September & $\begin{array}{l}0.238 * * * \\
(0.065)\end{array}$ & $\begin{array}{l}0.238 * * * \\
(0.065)\end{array}$ & $\begin{array}{l}0.264 * * * \\
(0.064)\end{array}$ & $\begin{array}{l}0.217 * * * \\
(0.065)\end{array}$ \\
\hline October & $\begin{array}{l}0.088 \\
(0.064)\end{array}$ & $\begin{array}{l}0.087 \\
(0.064)\end{array}$ & $\begin{array}{l}0.111^{*} \\
(0.064)\end{array}$ & $\begin{array}{l}0.063 \\
(0.065)\end{array}$ \\
\hline November & $\begin{array}{l}0.128 * * \\
(0.059)\end{array}$ & $\begin{array}{l}0.125^{* *} \\
(0.061)\end{array}$ & $\begin{array}{l}0.135^{* *} \\
(0.060)\end{array}$ & $\begin{array}{l}0.106^{*} \\
(0.060)\end{array}$ \\
\hline December & $\begin{array}{l}0.745 * * * \\
(0.058)\end{array}$ & $\begin{array}{l}0.742 * * * \\
(0.061)\end{array}$ & $\begin{array}{l}0.744 * * * \\
(0.061)\end{array}$ & $\begin{array}{l}0.722 * * * \\
(0.060)\end{array}$ \\
\hline Constant & $\begin{array}{l}0.839 * * * \\
(0.050)\end{array}$ & $\begin{array}{l}0.838 * * * \\
(0.050)\end{array}$ & $\begin{array}{l}0.373 * * * \\
(0.061)\end{array}$ & $\begin{array}{l}-.247 * * \\
(0.061)\end{array}$ \\
\hline R-Square & 0.051 & 0.051 & 0.074 & 0.086 \\
\hline F-Statistic & $22.9 * * *$ & $18.1 * * *$ & $25.8 * * *$ & $27.4 * * *$ \\
\hline
\end{tabular}

See Table 5 Sequence of low precipitation (drought) for at least two months significantly (at $1 \%$ level of significance) affects human needs, in other words $1 \mathrm{~mm}$ decrease in precipitation beyond $20 \mathrm{~mm}$ (less than 20mm) contributes to increasing HNI score by 0.31 on average in all three sub-models of Model 2 delineating higher poverty-related human needs, whereas increase by HNI score $0.335,0.308$ and 0.288 in models from model $2 \mathrm{~b}$ to model $2 \mathrm{~d}$. As said before, the rest of all the weather-related indicators in this study present insignificant association with poverty-related human needs. As far as controlled variables are concerned, $1 \%$ change (increase/decrease) in unemployment rate may change 
(increase/decrease) human needs by score 0.070 on average (statistically significant at $1 \%$ level of significance), longitude results show that $1^{\circ}$ movement from Western areas to Eastern areas in the United States may reduce human needs by score 0.006, whereas from North to South (latitude) results are not significant. Robust seasonality results reveal the implications of all these results for Model 2 during Fall-Winter season (August to December, October exclusive) showing statistically higher significance (1\% significance level) particularly in December (highest needs month). Consistently, the goodness of fitness values of both the models $(\mathrm{R} 2=0.066)$ shows that weather extremes, and extreme events along with unemployment rate, latitude and longitude as controlled indicators may cause to bring about 6.6 percent variation on average in human needs. Overall both the models are highly significant shown by FStatistic value.

Table 6: Pooled-OLS Seasonality Results of Model 2

\begin{tabular}{|c|c|c|c|c|}
\hline HNI & $\begin{array}{l}\text { Model 2a } \\
\text { Coefficient } \\
\text { s } \\
\text { (Standard } \\
\text { Error) } \\
\end{array}$ & $\begin{array}{l}\text { Model 2b } \\
\text { Coefficient } \\
\text { s } \\
\text { (Standard } \\
\text { Error) } \\
\end{array}$ & $\begin{array}{l}\text { Model 2c } \\
\text { Coefficient } \\
\text { s } \\
\text { (Standard } \\
\text { Error) } \\
\end{array}$ & $\begin{array}{l}\text { Model 2d } \\
\text { Coefficient } \\
\text { s } \\
\text { (Standard } \\
\text { Error) } \\
\end{array}$ \\
\hline \multicolumn{5}{|l|}{$\begin{array}{l}\text { Weather } \\
\text { Extremes }\end{array}$} \\
\hline Hot 1 & $\begin{array}{l}-.112 \\
(0.431)\end{array}$ & $\begin{array}{l}0.008 \\
(0.556)\end{array}$ & $\begin{array}{l}-.004 \\
(0.548)\end{array}$ & $\begin{array}{l}0.003 \\
(0.546)\end{array}$ \\
\hline Cold 1 & $\begin{array}{l}0.061 \\
(0.040)\end{array}$ & $\begin{array}{l}0.058 \\
(0.049)\end{array}$ & $\begin{array}{l}0.097 * * \\
(0.048)\end{array}$ & $\begin{array}{l}0.072 \\
(0.050)\end{array}$ \\
\hline $\begin{array}{l}\text { Low } \\
\text { Precipitation } 1\end{array}$ & $\begin{array}{l}0.236 * * * \\
(0.039)\end{array}$ & $\begin{array}{l}0.076 \\
(0.052)\end{array}$ & $\begin{array}{l}0.118 * * \\
(0.051)\end{array}$ & $\begin{array}{l}0.036 \\
(0.052)\end{array}$ \\
\hline $\begin{array}{l}\text { High } \\
\text { Precipitation } 1\end{array}$ & $\begin{array}{l}-.147 \\
(0.102)\end{array}$ & $\begin{array}{l}-.140 \\
(0.104)\end{array}$ & $\begin{array}{l}-.172^{*} \\
(0.103)\end{array}$ & $\begin{array}{l}-.125 \\
(0.102)\end{array}$ \\
\hline \multicolumn{5}{|l|}{$\begin{array}{l}\text { Extreme } \\
\text { Events }\end{array}$} \\
\hline Heat Wave 1 & & $\begin{array}{l}-.298 \\
(0.878)\end{array}$ & $\begin{array}{l}-.318 \\
(0.867)\end{array}$ & $\begin{array}{l}-.298 \\
(0.862)\end{array}$ \\
\hline Cold winter 1 & & $\begin{array}{l}-.010 \\
(0.069)\end{array}$ & $\begin{array}{l}0.006 \\
(0.068)\end{array}$ & $\begin{array}{l}-.042 \\
(0.068)\end{array}$ \\
\hline Drought 1 & & $\begin{array}{l}0.335 * * * \\
(0.072)\end{array}$ & $\begin{array}{l}0.308 * * * \\
(0.072)\end{array}$ & $\begin{array}{l}0.288 * * * \\
(0.071)\end{array}$ \\
\hline Flood 1 & & $\begin{array}{l}-.197 \\
(0.565)\end{array}$ & $\begin{array}{l}-.059 \\
(0.557)\end{array}$ & $\begin{array}{l}-.038 \\
(0.555)\end{array}$ \\
\hline \multicolumn{5}{|l|}{ Controlled } \\
\hline $\begin{array}{l}\text { Unemployme } \\
\text { nt Rate }\end{array}$ & & & $\begin{array}{l}0.070 * * * \\
(0.005)\end{array}$ & $\begin{array}{l}0.070 * * * \\
(0.005)\end{array}$ \\
\hline Latitude & & & & $\begin{array}{l}0.002 \\
(0.002)\end{array}$ \\
\hline Longitude & & & & $\begin{array}{l}-.006 * * * \\
(0.000)\end{array}$ \\
\hline \multicolumn{5}{|l|}{$\begin{array}{l}\text { Seasonality } \\
\text { Results }\end{array}$} \\
\hline February & -.088 & -.092 & -.092 & -.083 \\
\hline
\end{tabular}

\begin{tabular}{|c|c|c|c|c|}
\hline & $(0.057)$ & $(0.060)$ & $(0.059)$ & $(0.059)$ \\
\hline March & $\begin{array}{l}0.051 \\
(0.059)\end{array}$ & $\begin{array}{l}0.047 \\
(0.061)\end{array}$ & $\begin{array}{l}0.063 \\
(0.060)\end{array}$ & $\begin{array}{l}0.053 \\
(0.060)\end{array}$ \\
\hline April & $\begin{array}{l}0.023 \\
(0.062)\end{array}$ & $\begin{array}{l}0.016 \\
(0.062)\end{array}$ & $\begin{array}{l}0.035 \\
(0.062)\end{array}$ & $\begin{array}{l}0.009 \\
(0.062)\end{array}$ \\
\hline May & $\begin{array}{l}0.050 \\
(0.062)\end{array}$ & $\begin{array}{l}0.043 \\
(0.063)\end{array}$ & $\begin{array}{l}0.063 \\
(0.062)\end{array}$ & $\begin{array}{l}0.036 \\
(0.061)\end{array}$ \\
\hline June & $\begin{array}{l}0.047 \\
(0.062)\end{array}$ & $\begin{array}{l}0.039 \\
(0.063)\end{array}$ & $\begin{array}{l}0.058 \\
(0.062)\end{array}$ & $\begin{array}{l}0.033 \\
(0.062)\end{array}$ \\
\hline July & $\begin{array}{l}0.157 * * \\
(0.062)\end{array}$ & $\begin{array}{l}0.156 * * \\
(0.063)\end{array}$ & $\begin{array}{l}0.174 * * * \\
(0.065)\end{array}$ & $\begin{array}{l}0.150 * * \\
(0.062)\end{array}$ \\
\hline August & $\begin{array}{l}0.200 * * * \\
(0.062)\end{array}$ & $\begin{array}{l}0.207 * * * \\
(0.063)\end{array}$ & $\begin{array}{l}0.227 * * * \\
(0.062)\end{array}$ & $\begin{array}{l}0.203 * * * \\
(0.062)\end{array}$ \\
\hline September & $\begin{array}{l}0.242 * * * \\
(0.062)\end{array}$ & $\begin{array}{l}0.235 * * * \\
(0.063)\end{array}$ & $\begin{array}{l}0.253 * * * \\
(0.062)\end{array}$ & $\begin{array}{l}0.230^{* * * *} \\
(0.062)\end{array}$ \\
\hline October & $\begin{array}{l}0.092 \\
(0.061)\end{array}$ & $\begin{array}{l}0.094 \\
(0.062)\end{array}$ & $\begin{array}{l}0.112 * \\
(0.062)\end{array}$ & $\begin{array}{l}0.086 \\
(0.062)\end{array}$ \\
\hline November & $\begin{array}{l}0.144 * * \\
(0.061)\end{array}$ & $\begin{array}{l}0.155^{* *} \\
(0.060)\end{array}$ & $\begin{array}{l}0.167 * * \\
(0.060)\end{array}$ & $\begin{array}{l}0.151 * * \\
(0.061)\end{array}$ \\
\hline December & $\begin{array}{l}0.745 * * * \\
(0.058)\end{array}$ & $\begin{array}{l}0.738 * * * \\
(0.058)\end{array}$ & $\begin{array}{l}0.738 * * * \\
(0.057)\end{array}$ & $\begin{array}{l}0.728 * * * \\
(0.057)\end{array}$ \\
\hline Constant & $\begin{array}{l}0.822 * * * \\
(0.046)\end{array}$ & $\begin{array}{l}0.827 * * * \\
(0.047)\end{array}$ & $\begin{array}{l}0.359 * * * \\
(0.059)\end{array}$ & $\begin{array}{l}-.234 * * \\
(0.110)\end{array}$ \\
\hline R-Square & 0.049 & 0.052 & 0.076 & 0.086 \\
\hline F-Statistic & $23.8 * * *$ & $20.9 * * *$ & $29.6 * * *$ & $30.5^{* * *}$ \\
\hline
\end{tabular}

Note: $* * *$ significance level (1\%), ** significance level $(5 \%)$ $\& *$ significance level $(10 \%)$

\subsection{Discussion}

As precipitation extremes are less predictable than temperature extremes. Low precipitation, continuity of low precipitation (drought) and high precipitation impact human livelihoods and prosperity. Basic human needs i.e., Food, housing, clothing; medical/health needs, energy etc alter as a result of weather extremes. It is well understood that the Western part of the United States which contributes over 50 percent of the national valuable produces together with vegetables and fruits is prone to drought, agriculture is usually the earliest and most affected sector extreme low precipitation in the form of water shortage contribute to food shortage, particularly during summer and winter increase energy demands (gap between energy needs \& supply) aggravate existing confronts of poor communities in particular.

California as one of the largest contributing state to the U.S. economy through agriculture, energy production and recreation is likely to hit hardly by extreme events by drought in specific. The agriculture sector in California greatly depends on irrigation i.e., crops, vegetable and fruit production. Almond and walnut considered as multi-billion dollar industries are heavily water demanding industries, approximately $15 \%$ of the 
electricity in California is hydroelectric based. Low precipitation and its continuity causing water scarcity contribute to exacerbate their existing challenges in terms of increasing cost of production leading to increasing consumer cost to basic needs, spikes in food prices due to crop loss (widening demand-supply gap) and higher energy demands particularly in summer for cooling (air conditioners) and winter for heating (heaters).

Food which is a building block of health and well-being, every year droughts and wildfires contribute to widening demand/supply gap through crop damage creating food scarcity and homes burning. Drought can also directly or indirectly be the cause of future vulnerability. It can influence food and water security, threats to health through multi-channels (K. L. Ebi and $\mathrm{K}$. Bowen) can spoil water providing infrastructure and cause to decreases both the quality and quantity of protected water $(\mathrm{F}$. J. Warren and D. S. Lemmen). It can also contribute to forest fires resulting in the devastation of housing units, buildings, and other assets. Reduced water quality elevates medical needs, energy needs power outage in the form of electricity can influence medicine $\&$ health, food, etc. As an example, diabetes patients would be unable to put their insulin injections in refrigerators ultimately droughts cause to diminish living fulfillment through imposing limits to daily life activities, i.e., limiting outdoor recreational activities.

During summer and winter (i.e., from July to December, October exclusive) human needs go up, every year in December human needs sustain the highest. In summer water scarcity impacts creating competition for its usage between energy production and farming, mining (which requires a large quantity of water), recreation (water related) which are the sources of their livelihoods. Attributing to hotter summer earlier snowmelt in winter creates dry cold and less precipitation affecting tourism, health problems, need more clothes, energy demands rise to keep homes and themselves warm. Due to lesser resources and uneasy access to govt. Services and economic opportunities they cannot prepare in advance for such unpredictable climatic situation. Therefore they need immediate and specific assistance from their relatives, volunteer society members \& organizations.

An extended frequency and duration of dryness (droughts) along with increasing population which is predicted to increase by about $70 \%$ until 2050in Western areas of the United States may boost up basic needs dominantly in Southwest affecting water supply sources including Colorado River Basin. Having the highest poverty rate existing stresses of indigenous Americans (more than $2 \%$ population of the total population) in this region may further aggravate. Elderly and low-income households specifically in summer and winter that may not afford the increased burden of energy costs are mainly at higher risks of extreme weather events (G. Garfin et al). Additionally, in the Northwestern regions, growing population, reduced precipitation and projection of low precipitation particularly in summer increases energy demands (air conditioners), and supply concerns widening the gap between elevating electricity demands/supply worsening situation in future (P. Mote and A. Snover). Indigenous Americans living in remote areas are likely to face risks of health, undernourishment to weather extremes because of environment's dependent natural resources as their sustenance. The water shortage in the case of the droughts is one of the main issues, indigenous Americans face because a large number of them already depend on unfettered low-quality supplies of water (M. H. Redsteer and A. Native, I. Task, and F. Access).

Our results show that poverty-related human needs reduce in case of high precipitation. In other words, Western Americans need lesser emergency assistance as a result of high precipitation. The plausible reasons may be that because low precipitation causes to increase human needs through different channels, high precipitation especially in western US (agricultural region causes to diminish poverty-related human needs particularly in summer due to less water stress for agriculture and energy production for summer and in winter season delaying snowmelt reduces occurrence of dry cold and prolong tourism season, high precipitation reduces wildfires and droughts.

\section{Conclusion}

As precipitation is one of the most complicated climate variables to correctly forecast, however, its accurate forecasting can mitigate risks particularly of poor communities (I. WeatherBill). This research concluded that low precipitation and its sequence as drought causes to increase human needs assistance through nonprofits social security networks and decreases trust level in governments whereas the situation reverses in case of high precipitation human needs assistance through social security channels decreases as well as lower trust level in nonprofits. During summer (July-September) and winter (November-December), poor Americans have higher trust level in the Salvation Army rather than the governments indicating higher emergency assistance particularly in Westem remote and population concentrated areas of United States. The U.S. Salvation Army's human needs index (HNI) may be beneficial for targeting persistent poor population areas to address there better altering human needs emergency assistance requirements and trust level on governments in response to extreme climatic conditions and season. 
Appendix

Table A1: Correlation Matrix of Model 1

\begin{tabular}{|c|c|c|c|c|c|c|c|c|c|}
\hline & $\begin{array}{l}\mathbf{H} \\
\mathbf{N} \\
\mathbf{I}\end{array}$ & $\begin{array}{l}\text { H } \\
\text { ot }\end{array}$ & $\begin{array}{l}\text { C } \\
\text { ol } \\
\text { d }\end{array}$ & $\begin{array}{l}\text { Low } \\
\text { Precip } \\
\text { itation }\end{array}$ & $\begin{array}{l}\text { High } \\
\text { Precip } \\
\text { itation }\end{array}$ & $\begin{array}{l}\text { H } \\
\text { ea } \\
\text { t } \\
\text { w } \\
\text { av } \\
\text { e }\end{array}$ & $\begin{array}{l}\text { Col } \\
\text { d } \\
\text { wi } \\
\text { nte } \\
\text { r }\end{array}$ & $\begin{array}{l}\text { Dro } \\
\text { ught }\end{array}$ & $\begin{array}{l}\text { Fl } \\
\text { oo } \\
\text { d }\end{array}$ \\
\hline HNI & 1 & & & & & & & & \\
\hline Hot & $\begin{array}{l}0 . \\
02\end{array}$ & 1 & & & & & & & \\
\hline Cold & $\begin{array}{l}0 . \\
04\end{array}$ & $\begin{array}{l}- \\
0 . \\
0 \\
7\end{array}$ & 1 & & & & & & \\
\hline $\begin{array}{l}\text { Low } \\
\text { precipi } \\
\text { tation }\end{array}$ & $\begin{array}{l}0 . \\
08\end{array}$ & $\begin{array}{l}- \\
0 . \\
0 \\
2\end{array}$ & $\begin{array}{l}0 . \\
02\end{array}$ & 1 & & & & & \\
\hline $\begin{array}{l}\text { High } \\
\text { Precip } \\
\text { itation }\end{array}$ & $\begin{array}{l}- \\
0 . \\
02\end{array}$ & $\begin{array}{l}0 . \\
0 \\
2\end{array}$ & $\begin{array}{l}- \\
0 . \\
06\end{array}$ & -0.03 & 1 & & & & \\
\hline $\begin{array}{l}\text { Heat } \\
\text { wave }\end{array}$ & $\begin{array}{l}0 . \\
01\end{array}$ & $\begin{array}{l}0 . \\
5 \\
3\end{array}$ & $\begin{array}{l}- \\
0 . \\
04\end{array}$ & -0.01 & 0.03 & 1 & & & \\
\hline $\begin{array}{l}\text { Cold } \\
\text { winter }\end{array}$ & $\begin{array}{l}- \\
0 . \\
05\end{array}$ & $\begin{array}{l}- \\
0 . \\
0 \\
5\end{array}$ & $\begin{array}{l}0 . \\
66\end{array}$ & -0.01 & -0.05 & $\begin{array}{l}- \\
0 . \\
02\end{array}$ & 1 & & \\
\hline $\begin{array}{l}\text { Droug } \\
\text { ht }\end{array}$ & $\begin{array}{l}0 . \\
05\end{array}$ & $\begin{array}{l}- \\
0 . \\
0 \\
1\end{array}$ & $\begin{array}{l}- \\
0 . \\
02\end{array}$ & 0.61 & -0.02 & $\begin{array}{l}- \\
0 . \\
01\end{array}$ & $\begin{array}{l}- \\
0.0 \\
1\end{array}$ & 1 & \\
\hline Flood & $\begin{array}{l}- \\
0 . \\
01\end{array}$ & $\begin{array}{l}0 . \\
0 \\
3\end{array}$ & $\begin{array}{l}- \\
0 . \\
02\end{array}$ & -0.01 & 0.30 & $\begin{array}{l}0 . \\
05\end{array}$ & $\begin{array}{l}- \\
0.0 \\
1\end{array}$ & - & 1 \\
\hline
\end{tabular}

Table A2: Correlation Matrix of Model 2

\begin{tabular}{|c|c|c|c|c|c|c|c|c|c|}
\hline & $\begin{array}{l}\mathbf{H} \\
\mathbf{N} \\
\mathbf{I}\end{array}$ & $\begin{array}{l}\text { H } \\
\text { ot } \\
1\end{array}$ & $\begin{array}{l}\text { C } \\
\text { ol } \\
\text { d } \\
1\end{array}$ & $\begin{array}{l}\text { Low } \\
\text { Precip } \\
\text { itation } \\
1\end{array}$ & $\begin{array}{l}\text { High } \\
\text { Precipi } \\
\text { tation1 }\end{array}$ & $\begin{array}{l}\text { H } \\
\text { ea } \\
\mathbf{t} \\
\mathbf{w} \\
\text { av } \\
\text { e } \\
1\end{array}$ & $\begin{array}{l}\text { Col } \\
\text { d } \\
\text { win } \\
\text { ter } \\
1\end{array}$ & $\begin{array}{l}\text { Dro } \\
\text { ught } \\
1\end{array}$ & $\begin{array}{l}\text { Flo } \\
\text { od } \\
1\end{array}$ \\
\hline HNI & $\begin{array}{l}1 \\
0 .\end{array}$ & & & & & & & & \\
\hline Hot 1 & $\begin{array}{l}0 \\
0\end{array}$ & 1 & & & & & & & \\
\hline $\begin{array}{l}\text { Cold } \\
1\end{array}$ & $\begin{array}{l}0 . \\
0 \\
5\end{array}$ & $\begin{array}{l}- \\
0 . \\
0 \\
1\end{array}$ & 1 & & & & & & \\
\hline $\begin{array}{l}\text { Low } \\
\text { precip } \\
\text { itation } \\
1\end{array}$ & $\begin{array}{l}0 . \\
0 \\
7\end{array}$ & $\begin{array}{l}0 . \\
0 \\
2\end{array}$ & $\begin{array}{l}0 . \\
08\end{array}$ & 1 & & & & & \\
\hline $\begin{array}{l}\text { High } \\
\text { Precip } \\
\text { itation } \\
1\end{array}$ & $\begin{array}{l}- \\
0 . \\
0 \\
2\end{array}$ & $\begin{array}{l}0 . \\
0 \\
2\end{array}$ & $\begin{array}{l}- \\
0 . \\
06\end{array}$ & -0.03 & 1 & & & & \\
\hline $\begin{array}{l}\text { Heat } \\
\text { wave } \\
1\end{array}$ & $\begin{array}{l}0 . \\
0 \\
0\end{array}$ & $\begin{array}{l}0 . \\
6 \\
3\end{array}$ & $\begin{array}{l}0 . \\
00\end{array}$ & 0.02 & 0.03 & 1 & & & \\
\hline $\begin{array}{l}\text { Cold } \\
\text { winter } \\
1\end{array}$ & $\begin{array}{l}- \\
0 . \\
0 \\
2\end{array}$ & $\begin{array}{l}- \\
0 . \\
0 \\
1\end{array}$ & $\begin{array}{l}0 . \\
57\end{array}$ & 0.07 & -0.05 & $\begin{array}{l}0 . \\
00\end{array}$ & 1 & & \\
\hline $\begin{array}{l}\text { Droug } \\
\text { ht } 1\end{array}$ & $\begin{array}{l}0 . \\
0 \\
9\end{array}$ & $\begin{array}{l}0 . \\
0 \\
2\end{array}$ & $\begin{array}{l}0 . \\
08\end{array}$ & 0.67 & -0.02 & $\begin{array}{l}0 . \\
03\end{array}$ & $\begin{array}{l}0.0 \\
8\end{array}$ & 1 & \\
\hline $\begin{array}{l}\text { Flood } \\
1\end{array}$ & $\begin{array}{l}- \\
0 . \\
0 \\
3\end{array}$ & $\begin{array}{l}0 . \\
0 \\
3\end{array}$ & $\begin{array}{l}- \\
0 . \\
02\end{array}$ & -0.01 & 0.30 & $\begin{array}{l}0 . \\
05\end{array}$ & $\begin{array}{l}- \\
0.0 \\
1\end{array}$ & -0.01 & 1 \\
\hline
\end{tabular}

Table A3: Multicollinearity Test Results

\begin{tabular}{|c|c|c|c|c|c|}
\hline Model 1 & VIF $^{*}$ & $1 /$ VIF $^{* *}$ & Model 2 & VIF & 1/VIF \\
\hline Hot & 1.46 & 0.683 & Hot 1 & 1.67 & 0.598 \\
\hline Cold & 3.61 & 0.277 & Cold 1 & 2.40 & 0.416 \\
\hline $\begin{array}{l}\text { Low } \\
\text { precipitation }\end{array}$ & 1.66 & 0.603 & $\begin{array}{l}\text { Low } \\
\text { precipitation } 1\end{array}$ & 1.94 & 0.516 \\
\hline $\begin{array}{l}\text { High } \\
\text { Precipitation }\end{array}$ & 1.11 & 0.898 & $\begin{array}{l}\text { High } \\
\text { Precipitation } 1\end{array}$ & 1.05 & 0.955 \\
\hline Heat wave & 1.41 & 0.707 & Heat wave 1 & 1.67 & 0.598 \\
\hline Cold winter & 2.79 & 0.358 & Cold winter 1 & 1.84 & 0.544 \\
\hline Drought & 1.61 & 0.621 & Drought 1 & 1.85 & 0.542 \\
\hline Flood & 1.10 & 0.906 & Flood 1 & 1.04 & 0.965 \\
\hline $\begin{array}{l}\text { Unemployment } \\
\text { rate }\end{array}$ & 1.02 & 0.978 & $\begin{array}{l}\text { Unemployment } \\
\text { rate }\end{array}$ & 1.03 & 0.974 \\
\hline Latitude & 1.48 & 0.674 & Latitude & 1.41 & 0.711 \\
\hline Longitude & 1.24 & 0.806 & Longitude & 1.30 & 0.771 \\
\hline \multicolumn{6}{|l|}{ Months } \\
\hline February & 1.93 & 0.517 & February & 2.03 & 0.493 \\
\hline March & 1.99 & 0.503 & March & 2.10 & 0.475 \\
\hline April & 2.19 & 0.457 & April & 2.08 & 0.480 \\
\hline May & 2.32 & 0.432 & May & 2.10 & 0.477 \\
\hline June & 2.35 & 0.426 & June & 2.10 & 0.476 \\
\hline July & 2.37 & 0.422 & July & 2.09 & 0.477 \\
\hline August & 2.39 & 0.419 & August & 2.11 & 0.475 \\
\hline September & 2.33 & 0.429 & September & 2.09 & 0.477 \\
\hline October & 2.28 & 0.439 & October & 2.07 & 0.483 \\
\hline November & 1.98 & 0.505 & November & 1.98 & 0.505 \\
\hline December & 1.99 & 0.502 & December & 1.77 & 0.563 \\
\hline Mean VIF & 1.94 & & Mean VIF & 1.81 & \\
\hline
\end{tabular}

*Variance Inflation Rate, **Tolerance Factor

\section{References:}

- J. M. Melillo, Terese, (T.C.), Richmond, G. W. Yohe, and (eds), "Climate Change Impacts in the United States: The Third National Climate Assessment U.S. Global Change Res earch Program."

- EM-DAT, "The International Disaster Database," Centre for Research on the Epidemiology of Disasters. 2015.

- Frank Thomalla, Tom Downing, Erika Spanger-Siegfried, Guoyi Han, and Johan Rockström, "Reducing hazard vulnerability: towards a common approach between disaster risk reduction and climate adaptation," vol. 30, no. 1, pp. 39-48, 2006.

- J. M. Melillo, T. (T. C.. Richmond, and G. W. Yohe, "Climate Change Impacts in the United States," p. 148, 2014.

- "Final-Report HNI."

- P. Lal, J. R. R. Alavalapati, and E. D. Mercer, "Socioeconomic impacts of climate change on rural United States," Mitig. Adapt. Strateg. Glob. Chang., vol. 16, no. 7, pp. 819-844, 2011. Crossref

- D. Philip and M. Rayhan, "Vulnerability and poverty: What are the causes and how are they related?," ZEF-Discussion Pap. Dev. Policy, p. 28, 2004.

- N. Steinberg and C. Gannon, "Heat \& Social Inequity in the The United StatesFour Twenty Seven Climate Solutions," 2016.

- "USDA, Economic Research Service," Bureau ofEconomic Analysis and U.S. Census Bureau, 2015. [Online]. 
Available: https:/www.ers.usda.gov/data-products/. [Accessed: 28-May-2018].

- M. Fisher, "n the Empirical Finding of a Higher Risk of Poverty in Rural Areas : Is Rural Residence Endogenous to Poverty ?" vol. 30, no. 2, pp. 185-199, 2005.

- D. Fahey, K. Hibbard, J. Arnold, D. Easterling, L. Jewett, K. Kunkel, and A. Legrande, "LEAD AUTHORS," 2017.

- A. V Kislov and A. N. Krenke, "CLIMATE-RELATED HAZARDS."

- W. E. Riebsame, "Sustainability of the Great Plains in an Uncertain Climate," Gt. Plains Res. A J. Nat. Soc. Sci., vol. 1, no. 1, pp. 133-150, 1991.

- S. Hales, S. J. Edwards, and R. S. Kovats, "Impacts on health of climate extremes Social factors :," pp. 79-102.

- "The Human Needs Index A new analysis from The Salvation Army and," 2017.

- "Centers for Disease Control and Prevention," Mental Health and Stress-related Disorders, 2010. [Online]. Available:

http://www.cdc.gov/climatechange/effects/mental_health.h tm.

- O. Brown and IOM, "Migration and Climate Change," Int. Organ. Migr. Geneva, vol. IOM Migration no. 31, p. 64, 2008.

- N. A. Ysasi, I. Marini, D. A. Harley, N. A. Ysasi, I. Marini, and D. A. Harley, "Climate and Weather in the The United Statesand Its Impact on People with Disabilities in Rural Communities.".

- IPCC, Climate Change 2007 Synthesis Report. 2007.

- IPCC, Mitigation of climate change: Contribution of working group III to the fourth assessment report of the Intergovernmental Panel on Climate Change. 2007.

- T. C. Gap and R. Morello-Frosch, "The Climate Gap," pp. $1-32$.

- NOAA, "U.S. billion-dollar weather and climate disasters," National Centers for Environmental Information (NCEI), 2018.

- T. E. Davies, N. Banjara, and T. Tregenza, "A socioeconomic perspective on gear based management in an artisanal fishery in South West Madagascar," Fish. Manag. Ecol.,pp. 1-11, 2009. Crossref

- T. Montague, M. M. Planning, S. T. Bergeron, C. C. Dodge, S. M. Brown, G. Dion, W. Commission, C. R. Escott, and C. J. Greene, "THE TOWN OF MONTAGUE," 2014.

- "USDA," Economic Research Service, 2013. [Online]. Available: https://www.ers.usda.gov/topics/rural-economypopulation/rural-classifications/what-is-rural.aspx.

- E. Miller, B. Antonny, S. Hamamoto, and R. Schekman, "Cargo selection into COPII vesicles is driven by the Sec24p subunit," EMBO J., vol. 21, no. 22, pp. 61056113, 2002. Crossref

- G. Yohe and R. S. J. Tol, "Indicators for social and economic coping capacity-moving toward a working definition of adaptive capacity," Glob. Environ. Chang., vol. 12, no. 1, pp. 25-40, 2002. Crossref

- B. L. Turner II, R. E. Kasperson, and P. A. Matson, “A framework for vulnerability analysis in sustainability science," Proc. Natl. Acad. Sci. U. S. A., vol. 100, no. 14, pp. 8074-8079, 2003. $\underline{\text { Crossref }}$

- "USDA," Economic Research Service (ERS), 2015. [Online]. Available: https://www.ers.usda.gov/dataproducts/county-typology-codes/descriptions-and-maps/.

- American Community Survey, "American Community Survey,"https://www.census.gov/programs-

surveys/acs/data.html, 2015. [Online]. Available: https://www.census.gov/programs-surveys/acs/data.html.

- The United StatesCensus Bureau, "American Community Survey,"https://www.census.gov/programssurveys/acs/data.html, 2015.

- "USDA, The United StatesDepartment of Agriculture," ERS, Economic Research Service, 2010. [Online]. Available: https://www.ers.usda.gov/.

- N. A. Ysasi, I. Marini, and D. A. Harley, "Climate and Weather in the The United Statesand Its Impact on People with Disabilities in Rural Communities," 2018.

- J. M. Melillo, T. (T. C.. Richmond, and 2014 Gary W. Yohe, Eds., "Climate Change Impacts in the The United States Climate Change Impacts in the United States," p. 841, 2014.

- R. Horton, G. Yohe, W. Easterling, R. Kates, M. Ruth, E. Sussman, A. Whelchel, D. Wolfe, and F. Lipschultz, "Chapter 16: Northeast," Clim. Chang. Impacts The United StatesThird Natl. Clim. Assess., no. October, pp. 1-24, 2014.

- J. Walsh and D. Wuebbles, "Climate Change Impacts in the United States: The Third National Climate Assessment, Chapter 2: Our Changing Climate," Natl. Clim. Assess., no. October, pp. 19-67, 2014.

- S. C. Pryor and R. J. Barthelmie, "Can / will climate change impact the wind energy industry ? Why wind energy ?"

- S. C. Pryor, D. Scavia, C. Downer, M. Gaden, L. Iverson, R. Nordstrom, J. Patz, and G. P. Roberson, "Ch. 18: Midwest.," in Climate change impacts in the United States: The third national climate assessment, 2014, pp. 418-440.

- "National Centers for Environment Information," 2016. [Online]. Available: https://www.ncei.noaa.gov/.

- S. Pryor, D. Scavia, C. Downer, M. Gaden, L. Iverson, R. Nordstrom, J. Patz, and G. Roberson, "Midwest," Clim. Chang. Impacts The United States third Natl. Clim. assessment., pp. 418-440, 2014.

- L. M. Carter, J. W. Jones, L. Berry, V. Burkett, J. F. Murley, J. Obeys ekera, P. J. Schramm, L. M. Carter, J. W. Jones, and L Berry, "Climate Change Impacts in the United States Recommended Citation for Chapter Convening Lead Authors Lead Authors," U.S. Glob. Chang. Res. Progr., vol. 17, pp. 396 417, 2014.

- M. Minkler, E. Fuller-Thomson, and J. M. Guralnik, "Gradient of Disability across the Socioeconomic Spectrum 
in the United States," N. Engl.J. Med., vol. 355, no. 7, pp. 695-703, 2006. Crossref

- L. M. Carter, J. W. Jones, L. Berry, V. Burkett, J. F. Murley, J. Obeysekera, P. J. Schramm, and D. Wear, "Chapter 17: Southeast and the Caribbean: Climate Change Impacts in the United States: The Third National Climate Assessment," U.S. Glob. Chang. Res. Progr., no. October, pp. 396-417, 2014.

- D. C. Morton, M. E. Roessing, A. E. Camp, and M. L. Tyrrell, "Assessing the Environmental, Social, and Economic Impacts of Wildfire Assessing the Environmental, Social, and Economic Impacts of Wildfire," p. 59, 2003.

- G. Garfin, G. Franco, H. Blanco, A. Comrie, P. Gonzalez, T. Piechota, R. Smyth, and R. Waskom, "Southwest," Clim. Chang. The Impacts United States, pp. 462-486, 2014.

- P. Mote and A. Snover, "Chapter 21: Northwest," Natl. Clim. Assess., pp. 487-513, 2014.

- A. Community and S. Briefs, "Poverty : 2012 and 2013," no. September, pp. 1-9, 2014.

- K. Seefeldt, G. Abner, J. Bolinger, L. Xu, and J. Graham, "At Risk: America's poor during and after the Great Recession," 2012.

- E. Bucchignani, J. M. Gutierrez, M. Montesarchio, A. L. Zollo, G. Rianna, M. Iturbide, S. Herrera, and P. Mercogliano, "D2.1 - DEFINITION OF DIFFERENT EWIS, TO SUPPORT THE MANAGEMENT OF EUROPEAN CI 2 D2.1 - DEFINITION OF DIFFERENT EWIS, TO SUPPORT THE MANAGEMENT OF EUROPEAN CI Deliverable Title Deliverable D2.1: Definition of different EWIs, to support the management of Eu," 2014.

- S. K. Allen, V. Barros, I. Burton, D. L. Lendrum, O. D. Cardona, S. L. Cutter, O. P. Dube, K. L. Ebi, C. B. Field, J. W. Handmer, P. N. Lal, A. Lavell, K. J. Mach, M. D. Mastrandrea, G. A. McBean, R. Mechler, T. Mitchell, N. Nicholls, K. L. O’Brien, T. Oki, M. Oppenheimer, Pelling.M, G. Plattner, R. S. Pulwarty, S. I. Seneviratne, T. F. Stocker, M. K. Van Aalst, C. S. Vera, T. J. Wilbanks, and C. U. Press, "Managing the Risks of Extreme Events and Disasters to Advance Climate Change Adaptation," p. 30, 2011.

- C. M. Mills, J. E. Walsh, M. N. Martini, W. I. Gustafson, Q. Yang, and H. Xiao, "Journal of Geophysical Research: Atmospheres," pp. 674-688, 2014.

- I. SREX, "Weather and Climate Events.".

- M. Jahn, "Economics of extreme weather events: Terminology and regional impact models," Weather Clim. Extrem., vol. 10, pp. 29-39, 2015. Crossref

- W. Schlenker and M. J. Roberts, "Nonlinear temperature effects indicate severe damages to U.S. crop yields under climate change," Proc. Natl. Acad. Sci., vol. 106, no. 37, pp. 15594-15598, 2009. Crossref

- E. J. Powell and B. D. Keim, "Trends in daily temperature and precipitation extremes for the southeastern United States: 1948-2012," J. Clim., vol. 28, no. 4, pp. 1592-1612, 2015. Crossref

- R. E. Davis, P. C. Knappenberger, P. J. Michaels, and W. M. Novicoff, "Changing heat-related mortality in the United States," Environ. Health Perspect., vol. 111, no. 14, pp. 1712-1718, 2003. Crossref

- C. S. Cheng, M. Campbell, Q. Li, G. Li, H. Auld, N. Day, D. Pengelly, S. Gingrich, J. Klaassen, D. MacIver, N. Comer, Y. Mao, W. Thompson, and H. Lin, "Differential and combined impacts of extreme temperatures and air pollution on human mortality in south-central Canada. Part II: Future estimates," Air Qual. Atmos. Heal., vol. 2, no. 4, pp. 223 235, 2009. Crossref

- R. Basu and B. D. Ostro, "A multicounty analysis identifying the populations vulnerable to mortality associated with high ambient temperature in California," Am. J. Epidemiol., vol. 168, no. 6, pp. 632-637, 2008. Crossref

- N. Gouveia, S. Hajat, and B. Armstrong, "Socioeconomic differentials in the temperature-mortality relationship in São Paulo, Brazil," Int. J. Epidemiol., vol. 32, no. 3, pp. 390 397, 2003. Crossref

- O. Deschênes and M. Greenstone, "Climate Change, Mortality and Adaptation: Evidence from annual fluctuations in weather in the US," 2007.

- J. G. / S. J. Zivin, "Temperature Extremes, Health, and Human Capital," ERIC Inst. Educ. Sci., vol. 26, no. 1, pp. 3150, 2016.

- S. Lin, M. Luo, R. J. Walker, X. Liu, S. A. Hwang, and R. Chinery, "Extreme high temperatures and hospital admissions for respiratory and cardiovascular diseases," Epidemiology, vol. 20, no. 5, pp. 738-746, 2009. Crossref

- IPCC, "IPCC 2012, Summary for Policymakers," in Managing the Risks of Extreme Events and Disasters to Advance Climate Change Adaptation, 2012, pp. 1-19.

- F. Ackerman and E. a Stanton, "Climate Impacts on Agriculture: A Challenge to Complacency?" no. February, pp. 1-17, 2013.

- K. E. Kunkel, L. E. Stevens, S. E. Stevens, L. Sun, E. Janssen, D. Wuebbles, J. Rennells, A. DeGaetano, and J. G. Dobson, "NOAA Technical Report NESDIS 142-1 Regional Climate Trends and Scenarios for the U. S. National Climate Assessment. Part 1. The Climate of the Northeast U.S.," no. January, p. 79, 2013.

- K. L. Ebi and K. Bowen, "Extreme events as sources of health vulnerability: Drought as an example," Weather Clim. Extrem., 2016.

- F. J. Warren and D. S. Lemmen, Canada in a Changing Climate: Sector Perspectives on Impacts and Adaptation. 2014.

- "The Isolation of Collaboration: An Exploration of the Nature and Extent of Collaborative Practice in a Converter Academy.," 2016. 
- M. H. Redsteer, "Disaster risk assessment case study: Recent drought on the Navajo Nation, southwestern United States," vol. 53, no. 9, pp. 1689-1699, 2013.

- A. Native, I. Task, and F. Access, "Meeting the Access Goal Strategies for Increasing Access to Safe Drinking Water and Wastewater Treatment to American Indian and Alaska Native Infrastructure Task Force Access Subgroup," no. March 2008.

- I. WeatherBill, "Precipitation Averages, Seasonality, Volatility and Trends in the United States," 2007.

- J. Cromartie, "Historical Development of ERS Rural-Urban Classification Systems."

- "FARcodes StateSummaryTables 2010W ithAKandHI." 